\title{
Organizational Basis of the Formation and Activity of Beekeeping Associations in Russia
}

\author{
Skvortsova T.A.* \\ Rostov State University of Economics \\ 344012, 69, Bolshaya Sadovaya St. \\ Rostov-on-Don, Russian Federation \\ tas242@yandex.ru
}

\author{
Shatveryan N.G. \\ Rostov State University of Economics \\ 344012, 69, Bolshaya Sadovaya St. \\ Rostov-on-Don, Russian Federation \\ Kafedra37@bk.com
}

\author{
Alimova O.V. \\ Rostov State University of Economics \\ 344012, 69, Bolshaya Sadovaya St. \\ Rostov-on-Don, Russian Federation \\ Kafedra37@bk.com
}

\begin{abstract}
The article deals with organizational and legal aspects of the formation and activity of the beekeeping associations in Russia. It has been found that beekeeping products are mainly produced by small farms. In order to improve their economic stability and assist them in the organization of bee products marketing, it is important to form sustainable associations all over the Russian Federation. The authors analyzed the organizational and legal forms of the association (union) and agricultural consumer cooperative for the purpose of formation of the beekeeping association subjects. The study found that the association (union) is the preferable organizational and legal form for such units. At the same time, we identified imperfection of the legal regulation of this legal form and proposed some ways to improve it. Also, as a result of the study, the authors found that at the state level there are no legal mechanisms to support agricultural producers in the form of associations (unions). They are legally attached only for the agricultural consumer cooperatives. The authors propose to legally attach the possibility of providing state support to the associations (unions), uniting agricultural producers, including in the field of beekeeping, which will give impetus to the development of this sector of agriculture.
\end{abstract}

Keywords - component; formatting; style; styling; insert.

\section{INTRODUCTION}

Nowadays many countries around the world already recognized the need to produce and provide the population with environmentally friendly and healthy foods. Thus, the Russian Federation adopted Federal Law № 280-FL dated 03.08.2018 "On organic products and on amendments to certain legislative acts of the Russian Federation", this law was created to regulate relations associated with the production, storage, transportation, labeling and sale of organic products.

This normative legal act legislates such important concepts as "organic products", "organic agriculture", "organic producers" and contains requirements for organic production, rules for conformity of organic products, labeling, etc.
The natural honey is one of the ecologic and unique food products with many useful properties [1]. At present time the consumption of honey per capita in Russia is less than in the USA, Germany, Japan and some other economically developed states only by $0.5 \mathrm{~kg}$ per year [2].

According to the calculations of analysts of DISCOVERY Research Group, the volume of honey production in Russia in 2017 was 69489.6 tons, which was $0.4 \%$ less than it was in 2016. Also, we recorded the decrease of honey production by 9.5\% to 67736.4 tons in 2015 and this index of production growth was more than the same index in 2014 [3]. The Russian Federation occupies the 5th place in honey production by information of the Food and Agriculture Organization of the United Nations (FAO). Despite this fact, the volume of honey production in Russia is much less than in China; in China it was about 551476 tons in 2017 [4].

It should be noted that over $75 \%$ of food crops in the world are dependent on the pollination, and the main pollinators are bees; it means that bees help to produce the crop production. However, according to FAO, "there is an alarming decline in the pollinator populations, especially bees and butterflies, mainly due to the intensive agrotechnics in the farming practices, land-use changes, pesticides (including neonicotinoid insecticides), alien invasive species, diseases, pests and climate change" [5]. Therefore, in order to increase volume of the crop production, and, accordingly, to increase the level of the food security of the state, it is necessary to revive the population of pollinators.

Thus, if the natural honey production will increase in Russia, it will increase the bee-pollinators population, and the bee-pollinators increasing population will have a positive effect on providing the country's population with ecological food. To achieve these goals, it is necessary to form an organizational basis for business activities in the field of beekeeping.

At present almost $95 \%$ of Russian beekeeping farms are individual households of citizens or small independent farms 
and about $5 \%$ - in the public sector. It is about 5.3 million of the bee families being kept in the personal households of citizens now [6]. Thus, this branch of the agriculture is fragmented, requiring the formation of the effective mechanisms for its organization.

T.V. Epifanova, T.V. Shatkovskaya, N.G. Romanenko, T.A. Mosienko, M. Tkachenko (2017) pointed out the possibility of organizing small business in the form of cluster associations [7]. This thesis is also applicable to the organization of business in the field of beekeeping: the world experience in formation of the beekeeping clusters (India, China, Argentina) has shown the success of this type of the business organization in the field of the honey production and other bee products [8].

The beekeeping cluster will contribute to increasing labor productivity and increasing the production of honey and other beekeeping products, creating a system for training qualified personnel in the field of beekeeping and educating beekeepers, introducing a product quality management system to create internationally certified products, creating a distribution network for beekeeping products [8].

The approximate structure of the beekeeping cluster is shown in figure 1.

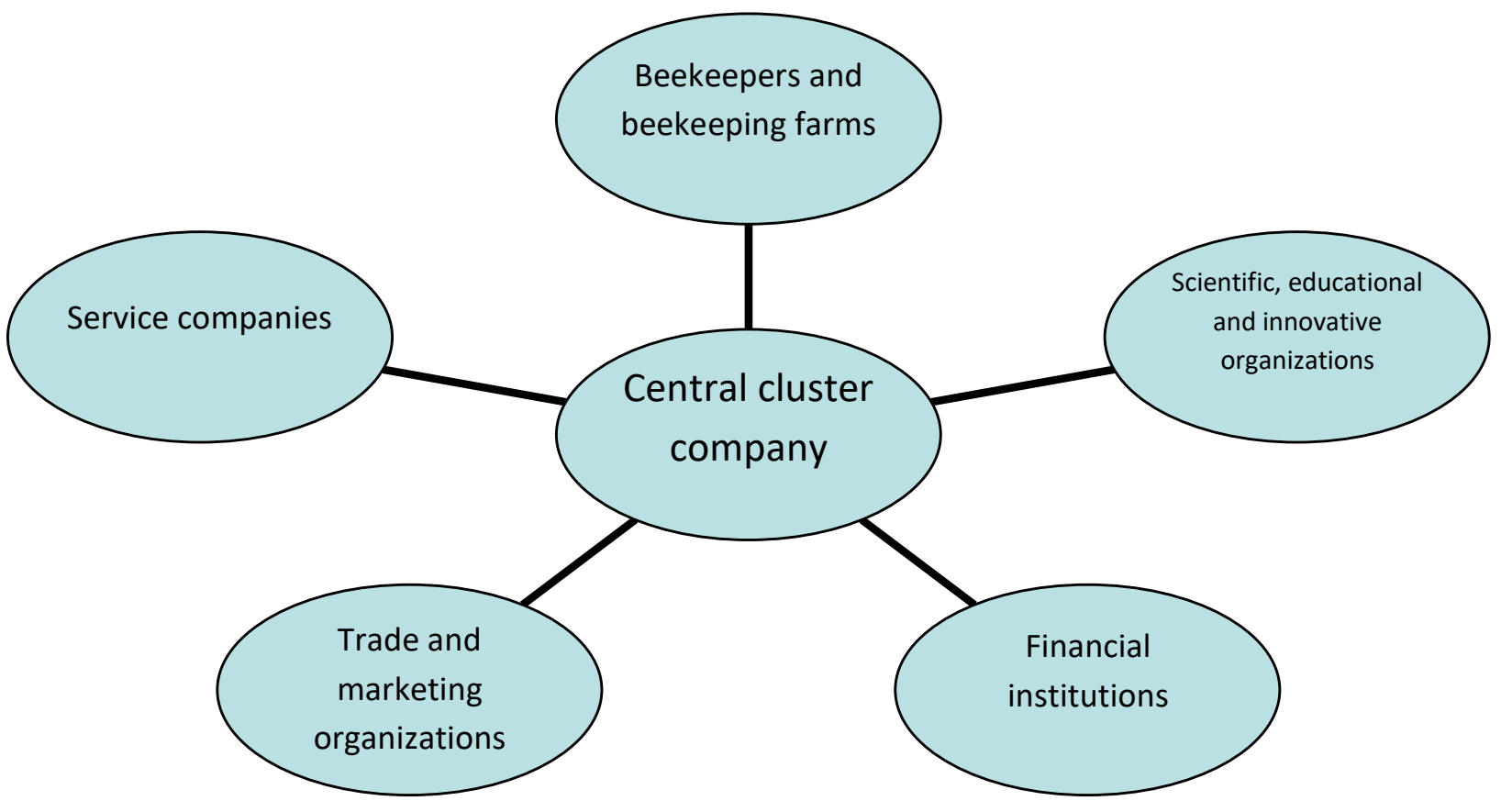

Fig 1. Approximate model of beekeeping cluster [8]

At the same time, it is possible to organize the sale and assistance in the production of beekeeping products in the whole country only by forming the association of beekeeping farms in one of the organizational-legal forms provided by the legislation of the Russian Federation. The integration of small and separate producers of beekeeping products into associations will give them economic stability and increase the competitiveness of their beekeeping products in the Russian and international markets.

\section{MATERIALS AND METHODS}

The research is based on the use of general scientific methods of cognition - dialectical, systemic, etc. For the analysis of various organizational legal forms of the associations of subjects (engaged in this type of business), we used the scientific methods of knowledge, typical of the legal science. They are structural and functional, regulatory and logical, technical and legal, linguistic methods.

\section{RESULTS}

The legislation of the Russian Federation provides the possibility of the associations formation in the field of business in a various organizational and legal forms, which are noncommercial legal subjects.

The analysis of the organization forms allowed by the legislation led us to the conclusion that the most suitable ones for organizing beekeeper associations are: associations (unions) and agricultural consumer cooperatives. 
Article 123.8 of the Civil Code of the Russian Federation indicates that "an association (union) is an association of legal entities and (or) citizens, based on voluntary or, in cases prescribed by law, mandatory membership and created to represent and protect common, including professional, interests to achieve socially useful goals, as well as other purposes not contradicting the law and having a non-commercial nature.

In the organizational legal form of the association there are such types of unions as 1) unities of persons with the purposes to coordinate their business activities, to represent and to protect thier property interests; 2) professional unities of citizens, who don't have the purpose to protect labour rights and interests of its members; 3) professional unities of citizens, who don't have the purpose to participate in labour relations (associations of appraisers, creative professionals and others); 4) self-regulatory organizations and their unities.

Thus, the civil legislation of the Russian Federation, taking into account occurred changes, implies a wide range of opportunities for the application of this organizational legal form. M.A. Kudryavtsev pointed out that the approach of the domestic legislator to the legal regulation of associations (unions) is changing, because the unions are transforming from the cumulative subjects, coordinating and organizing homogeneous, broad enough segments of the civil society, into the aggregating subjects, a kind of platforms for the identification, formation and expression of the widest and most diverse public interests, gaining in the framework of associations (unions) their institutionalized form [9].

It implies that the founders (participants) can assign a wide range of functions to such an association, when they are organizing a beekeeping association in such form. And all these functions will be indicated in the Charter of the organization, including such functions as: 1) to sell beekeeping products made by the members of the association; 2) to provide a variety of consulting and information services; 3) to organize exhibitions, fairs, etc.

But it should be admitted that associations (unions) are endowing with special legal capacity by the legislator. It means, that they can only have such civil rights and such civil obligations, that correspond to the purposes of their formation and activity. Which were fixed in the charter of such associations (unions).

The civil legislation implies that the individuals or the legal entities (in the amount of not less than 2) can be the founders (members) of the association (union) as a corporate noncommercial organization. A positive point in the legal status of associations is: "The association (union) members are not liable for its obligations, except in cases when the law or the charter of the association (union) provides for subsidiary liability of its members" (paragraph 3 of article 123.8 of the Civil Code).

Paragraph 3 of article 121.11 of the Civil Code determines that membership in the association (union) is inalienable. This means that the corporate rights and obligations of the association member are personal. They can't be transferred to another person, are not passed to the heirs of a deceased citizen, who was a member of the association, or to the successors of a legal entity (a former member of the association) [10]. In our opinion, the absence of the possibility to transfer an association membership for inheritance or as a result of universal legal succession in the reorganization of a legal entity is not reasonable and makes this legal form less attractive for the formation of business associations in the field of beekeeping. We believe that this legal justification should be adjusted.

Any association (union) member can be excluded from it in cases and in order that were prescribed in the charter of the association (union).

The management structure of the association (union) is indicated by its charter in accordance with the Civil Code. Thus, the highest management body of the organization is the general meeting of members of the association (union). Also the exclusive competence of the management body, along with the issues relating to all the corporate legal entities (indicated in paragraph 2 of article 65.3 of the Civil Code), is making decisions on the procedure for determining the amount and the method of payment of the membership fees, the additional property contributions of the association members to its property and on the amount of their subsidiary liability for the obligations of the association (union), if such liability is provided by the law or the charter.

In the association (union) a single executive body (Chairman, President, etc.) is forming. Permanent collegial executive bodies (Council, Board, Presidium, etc.) can be formed, too.

The authority of the association body can be terminated prematurely by the decision of the the highest management body of the association (union), for example in cases when: 1) this body grossly violates its duties; 2) this body can't properly conduct cases of the association; 3 ) if other serious causes were fixed.

Thus, the association (union) is an universal form of business combination, applicable to the beekeeping associations. The advantages of such organization form are: 1) the universality of such universality of such organizationallegal form; 2) the ability to provide in the charter of the organization a wide range of functions, for realizing business activities by its members; 3) the possibility of limiting the liability of members for the obligations of the association (union) 4) the universality of the management structure.

At the same time, the disadvantage of the beekeeping association in such form is the lack of mechanisms of the state support of these associations provided by the law.

Another organizational legal form in which a beekeeping association can be formed is an agricultural consumer cooperative.

According to article 4 of the Federal law of 08.12.1995 № 193-FL (ed. on 03.08.2018) "On agricultural cooperation" "agricultural consumer cooperative is an agricultural cooperative formed by agricultural producers and/or citizens engaged in personal subsidiary farming under the condition of their obligatory participation in the economic activity of the consumer cooperative".

Such cooperatives depend on the type of their activity. They are divided into processing, marketing (trade), service, supply, 
crop, livestock and other cooperatives. Also according to article 13 of the specified Federal law, the main condition for the functioning of a cooperative is: "volume of cooperative works that are performed for its members is not less than 50 percent of the entire volume of cooperative works".

Thus, the legislator is limiting the scope of the cooperatives business activity only by the sale of products or supply, etc. Also, the possibility of providing services to persons, who are not members of the cooperative, is limited.

The founders (members) of the cooperative are individuals and legal entities. According to paragraph 2 of article 14 of the Federal law of 08.12.1995 No. 193-FL (ed. on 03.08.2018) "On agricultural cooperation" "members of the consumer cooperative may be citizens and/or legal entities accepting the charter of the consumer cooperative, taking part in its economic activity and producing agricultural goods, as well as the citizens, keeping a personal subsidiary farm, citizens who are members or employees of agricultural organizations and/or peasant farms, citizens engaged in crop or livestock, and agricultural consumer cooperatives".

The cooperative members are responsible for their property for the consumer cooperative obligations. Thus, in accordance with article 123.3. of the Civil Code of the Russian Federation "within three months after the approval of the annual balance sheet, members of the consumer cooperative must cover the resulting losses by making additional contributions. The cooperative can be liquidate in the court by the the request of creditors in case of failure to perform the obligations".

One of the shortcomings of the beekeeping association in such a form is the responsibility of the cooperative members for its obligations.

Its highest body that must be obligatorily formed in the consumer cooperative carries out the management of the cooperative. It could be general meeting of members of the cooperative (meeting of commissioners), the board of the cooperative and/or the Chairman of the cooperative, the Supervisory Board of the cooperative.

The highest management bodies of the cooperative are: the chairman of the cooperative and the board of the cooperative. If the number of members of the cooperative is less than 25 , then the charter of the cooperative may only provide the election of the chairman of the cooperative and the vice-chairman. The Chairman of the cooperative, the Board of the cooperative should be elected by the general meeting of the cooperative members from the members of the cooperative for a term not exceeding five years. The Chairman of the cooperative is a member of the Board of the cooperative and in charge of it (article 26 of the Federal law of 08.12.1995 № 193-FL (ed. on 03.08.2018) "On agricultural cooperation").

Thus, consumer cooperatives have a more complicate and less variable management system than associations (unions).

At the same time, the organizational legal form of agricultural production cooperative has an advantage. In accordance with article 11 of the Federal law of 08.12.1995 № 193-FL (ed. on 03.08.2018) "On agricultural cooperation" "the state stimulates the formation and supports the activity of cooperatives by allocating funds from the federal budget and the budgets of the subjects of the Russian Federation in order to purchase and build processing and maintaining enterprises, the formation of credit and insurance cooperatives on the basis of plans and forecasts for the development of territories and target programs, carries out scientific, personnel and information support". It means that the measures of state support and stimulation of activity are provided to the agricultural consumer cooperatives, which is directly enshrined in the legislation.

\section{CONCLUSION}

Thus, the Russian legislation does not provide a universal legal form of creating a beekeeping association. The most correct legal form for these purposes is associations (unions) and agricultural consumer cooperatives.

Each legal form that was considered has its own advantages and disadvantages. But the preferred form of creating a beekeeping association is an association (union). This legal form allows one to most broadly determine the functions and types of association activity to achieve the goal of assisting members of such association in their business activity. Also the possibility to limit the liability of members for the obligations of the association (union) and the universality of the management system of such organization are reasonable.

At the same time, we think that it has unjustified the provision of civil law (point 3 of article 123.11 of the Civil Code of the Russian Federation); this provision indicates that membership in an association couldn't be alienated by the way of its transfer using inheritance or the succession procedure of legal entity reorganization.

In addition, it is necessary to consolidate the possibility of providing state support to associations (unions) that are uniting agricultural producers, which will stimulate the development of production and marketing of ecological products, beekeeping products, in particular.

\section{References}

[1] N.G. Romanenko, T.V. Epifanova, "Convergence of Food Standards into the Field of Beekeeping: Legal Aspect", Forestry journal, vol. 7, issue 2 (26), pp. 97-105, 2017.

[2] Condition and prospects of the Honey and Beekeeping Market in Russia. Retrieved from: o-paceke.ru/sostoyanie-i-perspektivyi-ryinka-meda/

[3] The Analysis of the Honey Market in Russia. Retrieved from: www.sitebs.ru/blogs/37179.html

[4] FAOSTAT Retrieved from: www.fao.org/faostat/en/\#data/QL

[5] Beeing Grateful to Our Pollinators: 6 Ways to Show our Gratitude to Bees, Butterflies and Other Vital Pollinators. Retrieved from: www.fao.org/fao-stories/article/en/c/1127922/

[6] T.A. Skvortsova, A.A. Milov, P.S. Zaitseva, "Organizational-legal Forms of Implementation of Innovative Activity", Gaps in the Russian Legislation, vol. 3, pp. 204-206, 2017.

[7] T.V. Epifanova, T.V. Shatkovskaya, N.G. Romanenko, T.A. Mosienko, M. Tkachenko, "The Legal Provision of Clustering in Russia as Environment for Development of Innovations", International Journal of Trade and Global Markets, vol. 10, issue 2-3, pp. 217-225, 2017.

[8] T.A. Skvortsova, I.P. Denisova, N.G. Romanenko, A.V. Sukhovenko, "Innovations and Support for Quality in Agriculture: A Case Study", European Research Studies Journal, vol. XXI, special issue 1, pp. 423431, 2018. 
[9] M.A. Kudryavtsev, "The Problem of Typology of Associations (Unions) as a Manifestation of Collisions of "Public" and "Private" Interests in the Modern Russian Law", Constitutional and Municipal Law, vol. 2, pp. 15 $-17,2016$.

[10] I.S. Shitkina and all The Corporate Law, vol. 1, I.S. Shitkina, Eds. Moscow: Statute, 2017.
[11] N.G. Vovchenko, T.V. Epifanova, N.S. Pogorelenko "Current situation and future potential of further integration between UK and EU", Austrian journal of humanities and social Sciences, vol. 5-6, pp. 148-152, 2015. 